\title{
The biological indicators studies of zooplankton in the Tigris River at the city of Baghdad
}

\author{
Khalid A. Rasheed ${ }^{1}$, Hussain A. Flayyh ${ }^{2}$, AbdulSalam T. Dawood ${ }^{3}$ \\ ${ }^{1}$ Biotechnology Research Center/Al-Nahrain University; \\ ${ }^{2}$ General Comp. for Elec. Indus./Ministry of Industry and Minerals; Ministry of Education and Scientific Research
}

\begin{abstract}
The study of biological indicators for zooplanktonis important factors in environmental studies to show the extent of the surrounding organisms, distribution and deployment environment affected. Zooplankton samples were collected from three stations on the Tigris River in the city of Baghdad using zooplankton net, specimens preserved and laboratory-diagnosed using internationally recognized classifications. Results show through the presence of relatively high abundance of zooplankton in the three stations and not affected by the city in addition to the species abundance is the other index gave few differences between stations, a lack of environmental pressures on these organisms in the station directory. Also, ShannonWeiner diversity Indexpointer gave no significant differences between the study stations.
\end{abstract}

Keywords- Tigris River, Baghdad, zooplankton, biological indicators.

\section{INTRODUCTION}

Life on earth depends on a balanced and accurate system of diversity, complement mutually and is losing species or group of species in an ecosystem, a reference to a defect in the function of this system (Elías- Gurtiérres et al., 2001).

The aquatic monitoring, and the study of the installation of their societies and its biodiversity, gives a direct description of the state of the water body, which is the primary purpose for the management of ecosystems and the preservation of this diversity (Smith, 1999).

Zooplankton are small aquatic animals have a certain ability to swim and manipulated by the water column currents to move long distances. Moving mostly in the upper reaches of the water, it has been found in deep water also, a variety of nutrition (heterotrophic). Many of which feeds on decaying organic material (detritivorous) and play a big role in connecting the food chain by feeding on phytoplankton (Solomon, 2009).

Zooplankton consist of three groups of fresh water, (Rotifers),(Copepods) and (Cladocerans). The rotiferais great one division in fresh water, but copepod and cladocera, both are large group called the crustaceans (Smith, 2001). The Tigris River, hasmany of the studies on the prevalence and distribution of zooplankton (Nashaat 2010, Abbas and Al-Lami,2001 and Al-Lami, 2001).

The aim of the research is to study the bio-indicators of the zooplankton community as a vital proof of the water quality of the Tigris River.

\section{MATERIALS AND METHODS}

\section{Study area}

The study area is situated in the center of Iraq to the flat alluvial plain, which represents the western part of the continental shelf is stable to the continent of Asia, or the socalled Mesopotamian zone.

The Tigris River enters the city of Baghdad and being slow in speeding component of a number of twists river and a number of islands. The river bed consists of sand and silt and clay (Al-Aboody 1992). The water level starts to increase in October and above in April. The river view variable inside the city of Baghdad, depending on water levels between 190-500m and speed of $1.42 \mathrm{~m} / \mathrm{s}$ at high discharge and $0.45 \mathrm{~m} / \mathrm{s}$ at the low discharge (Iraqi Water Resources, 2011). Three stations were chosen to study, a north of the Baghdad station at Taji Bridge (station 1),station 2 in the middle of Baghdad,the station 3, lying south of Baghdad (Figure 1). 


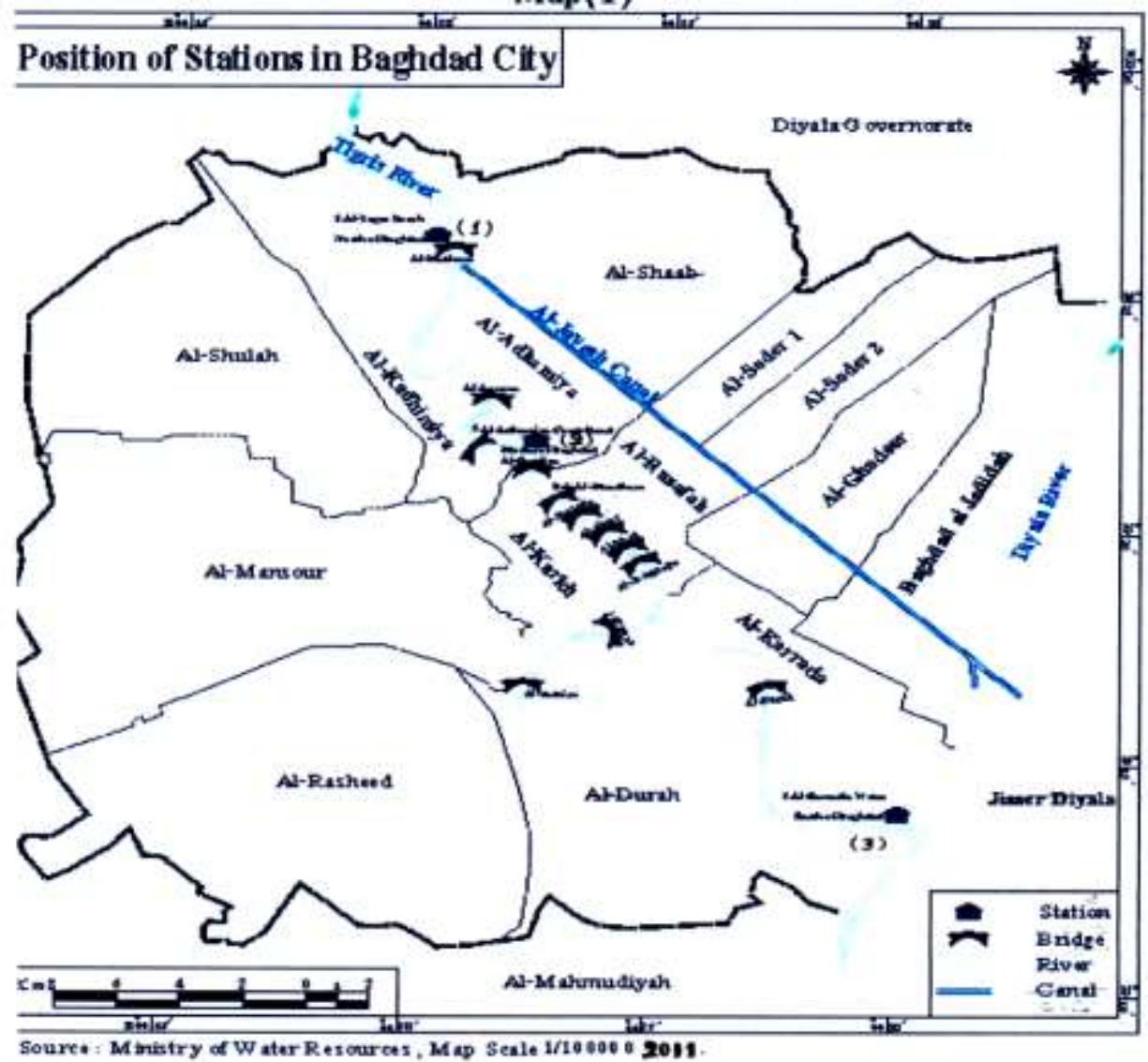

Fig. 1: Map of sampling stations (Iraq Water Resources, 2011)

(Source: Ministry of water Resources, Map Scale 1/10000

\section{Sampling collection}

This study began in March 2010 until February 2011, zooplankton collected quantitative and qualitative from a depth of $30 \mathrm{~cm}$ by passing 60 liters of water from the river across the plankton net with mesh $55 \mu \mathrm{m}$ in a small warehouse size of $50 \mathrm{ml}$, the sample preserved in $4 \%$ formalin solution. Diagnosed of zooplankton using a laboratory compound optical microscope using the keys (Edmondson 1959, Smith 2001, Petersen et al., 2010).The number of individuals calculated per cubic meter $\left(\right.$ Ind $/ \mathrm{m}^{3}$ ).

\section{Biological indicators}

Total Density and Relative abundance Index(Ra): This indicator was calculated using a derivative formula of Omori and Ikeda (1984) for calculating the relative abundance, as follows:

$$
\mathrm{Ra}=\frac{\mathrm{N}}{\mathrm{Ns}} \times 100
$$

$\mathrm{N}=$ total number of individuals per unit taxonomic in the sample.

Ns $=$ total number of individuals in the sample.
Since more than $70 \%$ prevalent types, $40-70 \%$ species abundant, $10-40 \%$ a fewer types and less than $10 \%$ of rare species

Shannon-Weiner Diversity Index $(\mathrm{H})$ :

This indicator was calculated monthly using ShannonWeiner formula as stated in (Floder and Sommer, 1999)

$$
\mathrm{H}=-\sum \frac{\mathrm{ni}}{\mathrm{N}} \ln \frac{\mathrm{ni}}{\mathrm{N}}
$$

Where ni= number of species

$$
\mathrm{N}=\text { Total number of individuals }
$$

And expressed a determination unit bit/Ind. (bit=one piece of information). The values that are lower than 1 bit/Ind. hadslightly varied, while more than 3bit/Ind. was highly versatile (Porto-Neto, 2003).

\section{The species Richness Index(D)}

This index calculated from Sklar(1985) as follows"

$$
D=\frac{(S-1)}{\log N}
$$


Where $\mathrm{s}=$ number of species

$\mathrm{N}=$ Total number of species

III. RESULTS AND DISCUSSION

Station 1 recorded a less total density of zooplankton, reached about 334 individual $/ \mathrm{m}^{3}$ in July and the highest in April 2010 amounted to 3003 individual $/ \mathrm{m}^{3}$ out of 76 taxonomic units (Figure 2).

Total density and relative abundance index (Ra):

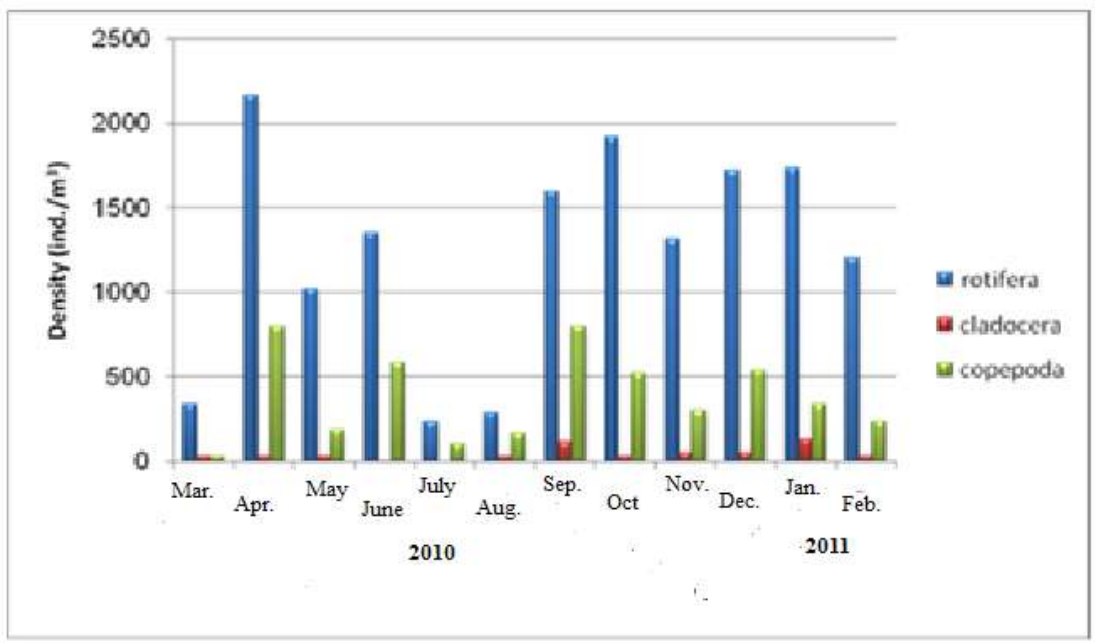

Fig.2: Total density of zooplankton in the station 1

While the total density ranged at the station 2 between 817 individual $/ \mathrm{m}^{3}$ in March 2010, and the highest density recorded in April 2010 and it was of 6018 individual $/ \mathrm{m}^{3}$ from 64 taxonomic units (Figure 3).

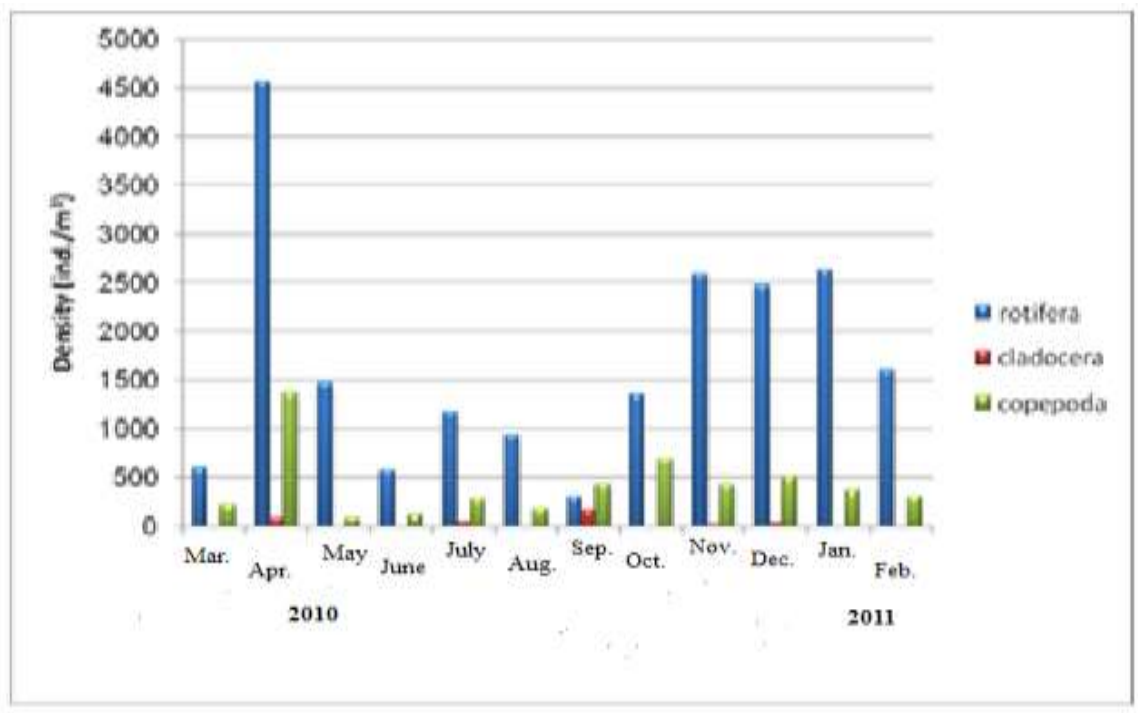

Fig.3: Total density of zooplankton in the station 2

While station 3 recorded the lowest density of zooplankton in the August 2010 reached about 235 individual $/ \mathrm{m}^{3}$ and higher density has recorded in April 2010 with 4336 individual $/ \mathrm{m}^{3}$ from 61 taxonomic units (Figure 4). 


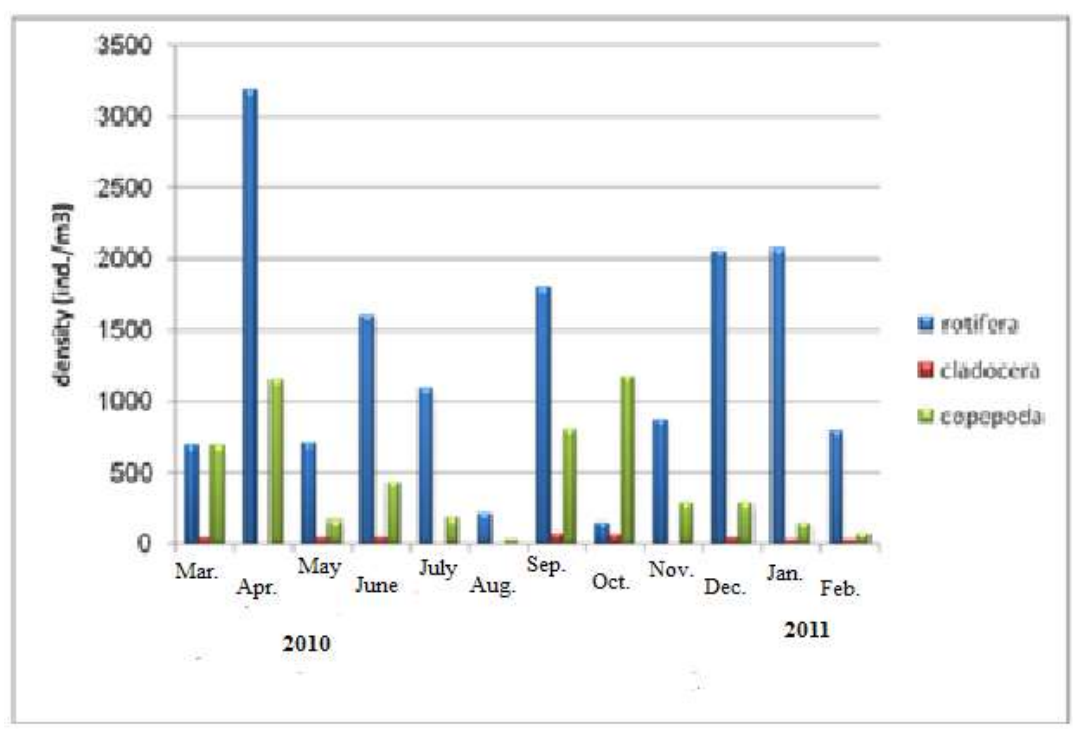

Fig.4: Total density of zooplankton in the station 3

Station 2 also recorded the highest total number of zooplankton (26.612 individual $/ \mathrm{m}^{3}$, while the lowest number in the station 1 , which amounted to 20.074 individual $/ \mathrm{m}^{3}$.

The rotifera recorded the highest density compared to other groups with percentage $76.6 \%$ (Figure 5) which is most prevalent among zooplankton groups because of its ability to reproduce parthenogenesis for several generations, high fertility and their response is very rapid for environmental changes that make them are used as a guide to changing water quality (Rajashekar et al., 2009). This is evident from many of the research (Shekha, 2008, Nashaat, 2010).

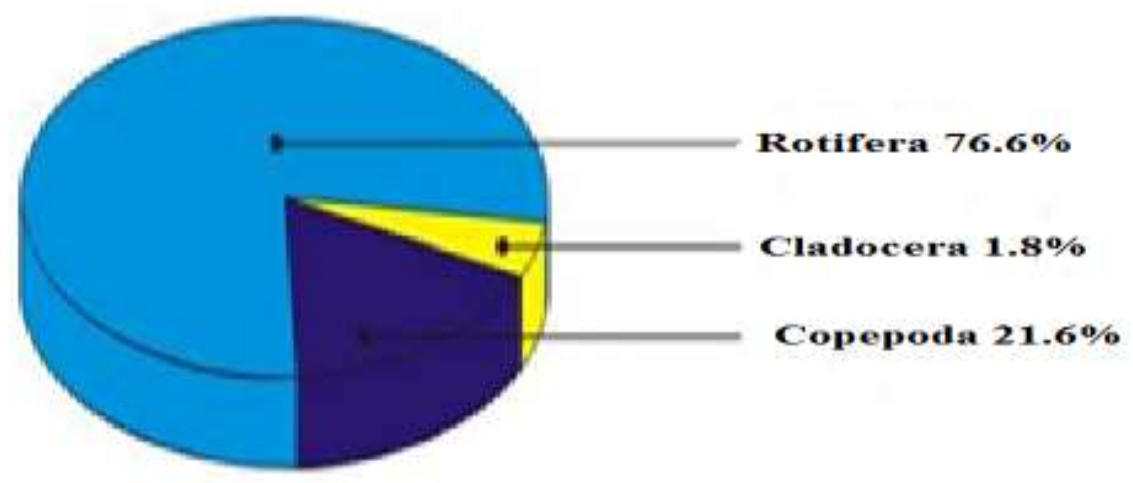

Fig.5: The percentages of zooplankton in the Tigris River at the city of Baghdad

Table 1 shows the proportions of the emergence of the species in the search for each station, where rotifera recorded the highest percentage of the species in station 1, where, the species Keratella cochlearis have the higher percentage(15.34\%) followed by Monostyla sp. with $10.42 \%$,thenPhilodina roseola by $9.39 \%$ and Polyarthra $\mathrm{sp}$ with $6.82 \%$ where the lowest percentages distributed among the rest of the species (Figure 6).
While in station 2 the relative abundance of rotifera species distributed as follows: $K$. cochlearis 14\%, Monostyla sp. $11.42 \%$, followed by Philodina roseola by $8.53 \%$, and the lowest percentage distributed among the rest of rotifera species. In station 3,P. roseola recorded the highest proportion in comparison with other types of rotifera (18.92\%), followed by K.cochlearis $(15.22 \%$ ) and Monostyla sp. (10.8\%). 
Table.1: The relative abundance of zooplankton in the three stations, and the appearance ratios, where $(R)$ rare, less than 10\%,

(La) less abundant 40-10\% (A), abundant species appearing 70-40\% and dominant species (D) more than $70 \%$.

\begin{tabular}{|c|c|c|c|c|}
\hline & Taxa / Staion & 1 & 2 & 3 \\
\hline \multicolumn{5}{|c|}{ ROTIFERA } \\
\hline 1 & Asplanchna priodonta & $\mathrm{R}$ & $\mathrm{R}$ & $\mathrm{R}$ \\
\hline 2 & Brachionus sp. & $\mathrm{R}$ & $\mathrm{R}$ & $\mathrm{R}$ \\
\hline 3 & Brachionus angularis & $\bar{R}$ & $\mathrm{R}$ & $\bar{R}$ \\
\hline 4 & Brachionus calyciforus & $\mathrm{R}$ & $\mathrm{R}$ & $\mathrm{R}$ \\
\hline 5 & Brachionus caudate & - & - & $\mathrm{R}$ \\
\hline 6 & Brachionus falcatus & $\mathrm{R}$ & $\mathrm{R}$ & - \\
\hline 7 & Brachionus havanaenis & $\mathrm{R}$ & - & - \\
\hline 8 & Brachionus plicatilis & $\bar{R}$ & $\mathrm{R}$ & $\mathrm{R}$ \\
\hline 9 & Brachionus quadridentata & $\mathrm{R}$ & $\mathrm{R}$ & $\bar{R}$ \\
\hline 10 & Cephalodella sp. & $\mathrm{R}$ & $\mathrm{R}$ & $\mathrm{R}$ \\
\hline 11 & Cephalodella gibba & $\mathrm{R}$ & $\mathrm{R}$ & $\mathrm{R}$ \\
\hline 12 & Colurella sp. & $\bar{R}$ & - & $\bar{R}$ \\
\hline 13 & Colurella adriatica & $\mathrm{R}$ & $\mathrm{R}$ & $\mathrm{R}$ \\
\hline 14 & Colurella obtuse & $\mathrm{R}$ & $\mathrm{R}$ & $\mathrm{R}$ \\
\hline 15 & Colurella uncinata & $\mathrm{R}$ & $\mathrm{R}$ & $\bar{R}$ \\
\hline 16 & Collotheca ornate & $\mathrm{R}$ & $\mathrm{R}$ & $\mathrm{R}$ \\
\hline 17 & Conochilus unicornis & - & - & $\mathrm{R}$ \\
\hline 18 & Eosphora sp. & $\mathrm{R}$ & $\mathrm{R}$ & $\mathrm{R}$ \\
\hline 19 & Eosphora najas & $\mathrm{R}$ & $\mathrm{R}$ & $\mathrm{R}$ \\
\hline 20 & Euchlanis deflexa & - & - & $\mathrm{R}$ \\
\hline 21 & Euchlanis dilatata & $\mathrm{R}$ & $\mathrm{R}$ & $\mathrm{R}$ \\
\hline 22 & Euchlanis pyriformis & - & $\mathrm{R}$ & - \\
\hline 23 & Euchlanis triqetra & $\mathrm{R}$ & - & $\mathrm{R}$ \\
\hline 24 & Filinia longuseta & $\mathrm{R}$ & $\mathrm{R}$ & $\mathrm{R}$ \\
\hline 25 & Filinia opoliensis & - & - & $\mathrm{R}$ \\
\hline 26 & Hexartha mira & $\mathrm{R}$ & $\mathrm{R}$ & $\mathrm{R}$ \\
\hline 27 & Keratella sp. & $\mathrm{R}$ & $\mathrm{R}$ & - \\
\hline 28 & Keratella cochlearis & $\mathrm{La}$ & $\mathrm{La}$ & $\mathrm{La}$ \\
\hline 29 & Keratella hiemalis & $\mathrm{R}$ & $\mathrm{R}$ & $\mathrm{R}$ \\
\hline 30 & Keratella quadrata & $\mathrm{R}$ & $\mathrm{R}$ & $\mathrm{R}$ \\
\hline 31 & Keratella valga. & $\mathrm{R}$ & $\mathrm{R}$ & $\mathrm{R}$ \\
\hline 32 & Lecane sp. & $\mathrm{R}$ & $\mathrm{R}$ & - \\
\hline 33 & Lecane depressa & - & - & $\mathrm{R}$ \\
\hline 34 & Lecane elasma & $\mathrm{R}$ & $\mathrm{R}$ & $\mathrm{R}$ \\
\hline 35 & Lecane luna & $\mathrm{R}$ & $\mathrm{R}$ & $\mathrm{R}$ \\
\hline 36 & Lecane ohioensis & $\mathrm{R}$ & $\mathrm{R}$ & $\mathrm{R}$ \\
\hline 37 & Lepadella sp. & $\mathrm{R}$ & $\mathrm{R}$ & - \\
\hline 38 & Lepadella ovalis & $\mathrm{R}$ & $\mathrm{R}$ & $\mathrm{R}$ \\
\hline 39 & Lepadella patella & $\mathrm{R}$ & $\mathrm{R}$ & $\mathrm{R}$ \\
\hline 40 & Macrochaetus subquadretus & - & $\mathrm{R}$ & - \\
\hline 41 & Manfredium cadaetytotum & - & - & $\mathrm{R}$ \\
\hline 42 & Monommata grands & $\mathrm{R}$ & $\mathrm{R}$ & $\mathrm{R}$ \\
\hline 43 & Monostyla sp. & $\mathrm{La}$ & $\mathrm{La}$ & $\mathrm{La}$ \\
\hline
\end{tabular}




\begin{tabular}{|c|c|c|c|c|}
\hline 44 & Monostyla bulla & $\mathrm{R}$ & $\mathrm{R}$ & $\mathrm{R}$ \\
\hline 45 & Monostyla closterocerca & $\bar{R}$ & $\mathrm{R}$ & $\mathrm{R}$ \\
\hline 46 & Monostyla lunaris & $\mathrm{R}$ & $\mathrm{R}$ & $\mathrm{R}$ \\
\hline 47 & Mytilina mucronata & - & - & $\mathrm{R}$ \\
\hline 48 & Mytilina ventralis & $\mathrm{R}$ & - & - \\
\hline 49 & Notholca sp. & $\mathrm{R}$ & - & - \\
\hline 50 & Notholca acuminate & $\mathrm{R}$ & $\mathrm{R}$ & - \\
\hline 51 & Notholca striata & - & $\mathrm{R}$ & - \\
\hline 52 & Philodina $\mathrm{sp}$. & - & $\mathrm{R}$ & - \\
\hline 53 & Philodina roseola & $\mathrm{R}$ & $\mathrm{R}$ & $\mathrm{La}$ \\
\hline 54 & Platyias patulus & - & $\mathrm{R}$ & - \\
\hline 55 & Platyias quadricorins & - & $\mathrm{R}$ & $\mathrm{R}$ \\
\hline 56 & Polyarthera sp. & $\mathrm{R}$ & $\mathrm{R}$ & - \\
\hline 57 & Polyarthera dolichoptera & $\mathrm{R}$ & $\mathrm{R}$ & $\mathrm{R}$ \\
\hline 58 & Polyarthera vulgaris & $\mathrm{R}$ & $\mathrm{R}$ & $\mathrm{R}$ \\
\hline 59 & Synchaeta sp. & $\mathrm{R}$ & $\mathrm{R}$ & $\mathrm{R}$ \\
\hline 60 & Synchaeta oblonga & $\mathrm{R}$ & $\mathrm{R}$ & $\mathrm{R}$ \\
\hline 61 & Synchaeta pectinata & - & $\mathrm{R}$ & - \\
\hline 62 & Testudinella patina & $\mathrm{R}$ & $\mathrm{R}$ & $\mathrm{R}$ \\
\hline 63 & Trichocerca sp. & $\mathrm{R}$ & $\mathrm{R}$ & $\mathrm{R}$ \\
\hline 64 & Trichocerca capucina & $\mathrm{R}$ & - & $\mathrm{R}$ \\
\hline 65 & Trichocerca longiseta & $\mathrm{R}$ & $\mathrm{R}$ & $\mathrm{R}$ \\
\hline 66 & Trichocerca procellus & $\mathrm{R}$ & $\mathrm{R}$ & $\mathrm{R}$ \\
\hline 67 & Trichocerca pusilla & - & - & $\mathrm{R}$ \\
\hline 68 & Trichotria tetractis & $\mathrm{R}$ & $\mathrm{R}$ & $\mathrm{R}$ \\
\hline 69 & Vanoyella globosa & - & - & $\mathrm{R}$ \\
\hline \multicolumn{5}{|c|}{ CLADOCERA } \\
\hline 1 & Alona sp. & $\mathrm{La}$ & $\mathrm{La}$ & $\mathrm{La}$ \\
\hline 2 & Alona guttata & $\mathrm{R}$ & - & $\mathrm{R}$ \\
\hline 3 & Bosmina sp. & - & - & $\mathrm{R}$ \\
\hline 4 & Bosmina coregoni & $\mathrm{R}$ & $\mathrm{R}$ & $\mathrm{La}$ \\
\hline 5 & Bosmina longirostris & $\mathrm{La}$ & - & $\mathrm{R}$ \\
\hline 6 & Camptocercus rectirostris & $\mathrm{La}$ & $\mathrm{La}$ & - \\
\hline 7 & Ceriodaphnia sp. & $\mathrm{R}$ & $\mathrm{La}$ & $\mathrm{La}$ \\
\hline 8 & Chydorus sp. & $\mathrm{R}$ & - & $\mathrm{La}$ \\
\hline 9 & Chydorus sphaericus & $\mathrm{La}$ & $\mathrm{R}$ & $\mathrm{La}$ \\
\hline 10 & Daphnia sp. & $\mathrm{R}$ & $\mathrm{R}$ & - \\
\hline 11 & Ilyocryptus sordidus & $\mathrm{R}$ & - & - \\
\hline 12 & Simocephalus sp. & - & - & $\mathrm{R}$ \\
\hline \multicolumn{5}{|c|}{ COPEPODA } \\
\hline 1. & Calanoida & $\mathrm{R}$ & $\mathrm{R}$ & $\mathrm{R}$ \\
\hline 2. & Cyclops & $\mathrm{D}$ & $\mathrm{D}$ & A \\
\hline 3. & Cyclopoida nauplus & - & - & $\mathrm{La}$ \\
\hline 4. & Diaptoms sp. & $\mathrm{R}$ & - & - \\
\hline 5. & Harpacticoida & $\mathrm{R}$ & $\mathrm{R}$ & $\mathrm{La}$ \\
\hline 6. & Macrocyclops & $\mathrm{R}$ & $\mathrm{R}$ & $\mathrm{R}$ \\
\hline
\end{tabular}




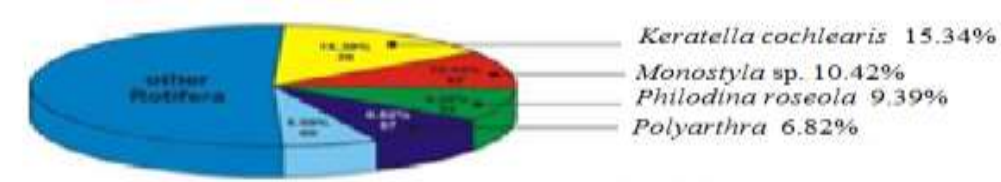

Percentage of rotifera in station 1

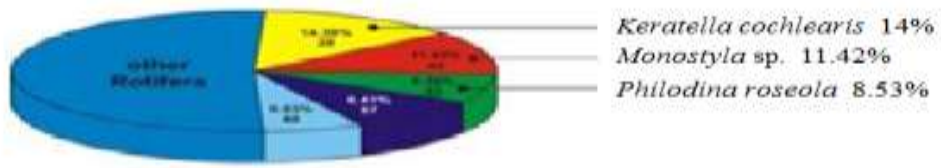

Percentage of rotifera in station 2

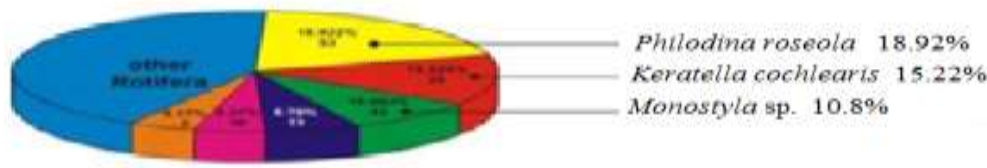

Percentage of rotifera in station 3

Fig.6: The percentage of rotifera in the three stations

The lack of a recording of values for the relative abundance index of rotifera gives a clear indication of the lack of environmental pressures in the river during the search, which may offer suitable conditions for the prosperity of certain types of resistance to these pressures and achieve overcome other species (Ahmad, etal., 2011).

The cladocera density ranged between (zero) in some months of the study to a higher intensity registered at the station 2 in September 2010 by 166 individual $/ \mathrm{m}^{3}$ (Figure 2 ). The relative abundance index refers to that the
speciesBosmina longirostrisdominant at the station 1 by $25 \%$, followed by Camptocercus rectirostris by $16.58 \%$ and Alona sp. by $13.9 \%$. In the station 2 Alona sp. recorded the highest percentage( $38 \%)$, thenCeriodaphnia sp. witha rate of $23.7 \%$ and then Camptocercus rectirostris(14.2\%). Ceriodaphnia sp recorded the highest percentage at station 3 with $22 \%$, then type Bosmina coregoniwitha rate of $16.88 \%$, followed by Chydorus sp. which scored about $16.5 \%$ (Figure 7).

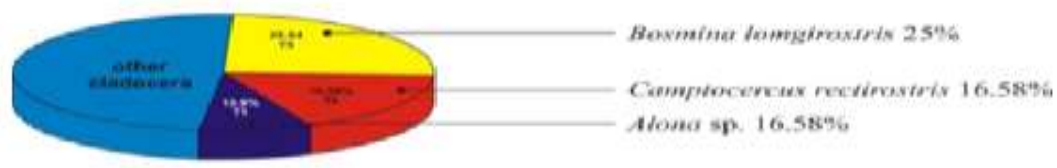

percentage of cladocera in station 1

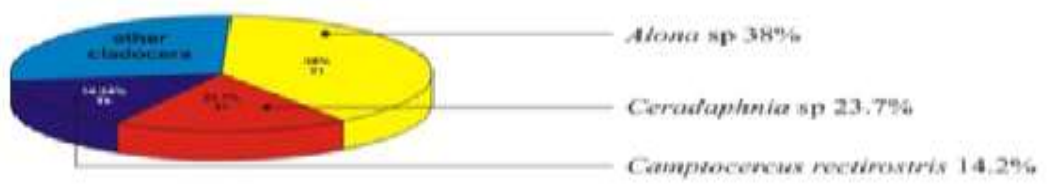

percentage of cladocera in station 2

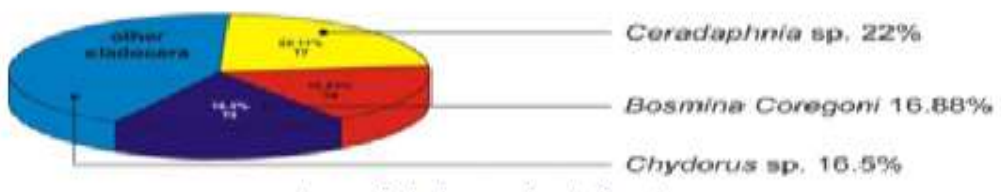

percentage of cladocera in station 3

Fig.7: The percentage of cladocera in the three stations 
The total density of cladocera in the study stations recorded as follows:station 1 ranged from 34 individual $/ \mathrm{m}^{3}$ in March 2010 to 800 individuals $/ \mathrm{m}^{3}$ in April 2010. The station 2, ranged from 184 individual $/ \mathrm{m}^{3}$ in May 2010 to 1367 individuals $/ \mathrm{m}^{3}$ in April 2010. While station 3 recorded about 17 individuals $/ \mathrm{m}^{3}$ in August 2010 to 1175 individuals $/ \mathrm{m}^{3}$ in October 2010 .
The relative abundance of taxonomic units of copepoda guide to that the Cyclops is the most abundant in all studied stations compared to other taxonomic units of the same group with the rates of $84 \%$ in the station 1 and $88.58 \%$ in the station 2 and $61.80 \%$ in the station 3 (Fig. 8).

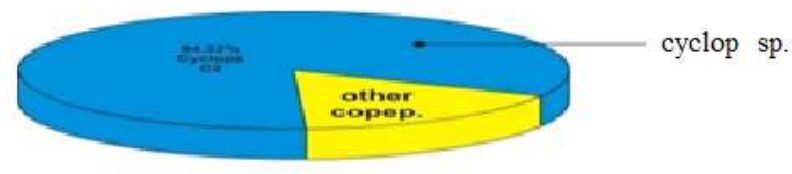

station 1

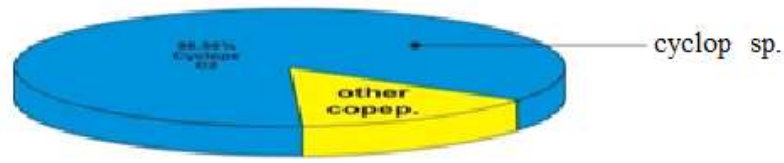

station 2

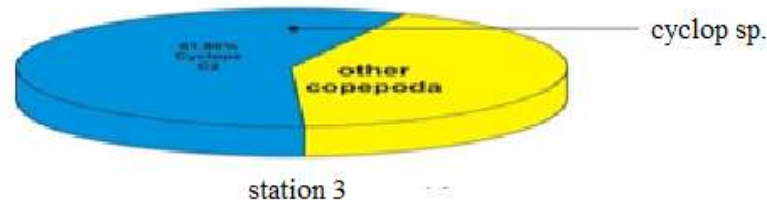

Fig.8: The percentages of copepoda in the three stations

In general, the relative density of the previous taxonomic units a few somewhat (40-10\%), depending on the relative abundance index. The species that did not mention, it was rare (less than 10\%) and the total stations appeared in this study was about 12 species, mostly classified as evidence of organic pollution (Ahmad et al., 2011).

From the above, it illustrated the lack of taxonomic units with the increase in the relative density and this means the availability of limited types have an ability to living conditions in the river. The difference in cladocera density may be due to the increase associated with an increased appropriate food (Claps et al., 2004), and that their numbers are affected by concentrations of salts and organic matter in the water, and the different larval stages of cladocera formed the highest percentage of the total density, and this is what consistent with (Al-Lami, 2001).

\section{Species Richness Index (D)}

This is an indicator expresses the fertile and rich area of study, and is described as the absolute number of taxonomic units in bio-aggregation, somewhere within the body of water,and the increase in the abundance of taxonomic units of index associatedwith the health and safety of the water ecosystem, and to measure the abundance of taxonomic units covers changes in the aquatic invertebrate community (Barbour et al., 1999).

In this study rotifera group overcame $76 \%$ (out of 69 units taxonomic) for zooplankton and others, while copepoda recorded 6 taxed at a ratio of $21.6 \%$ and $1.8 \%$ for cladocera (containing 12 units taxonomic).

Station 1 recorded 2.77 for the species richness in July to 8.84 in October. At station 2 it ranged from 4.07 in May to 8.52 in September. While at the station 3 ranged from 2.53 in August to 8.17 in September (Fig. 9). It has been observed the lowest value was recorded between stations in the station 3 during August and the highest value recorded in the station 1 in October. 


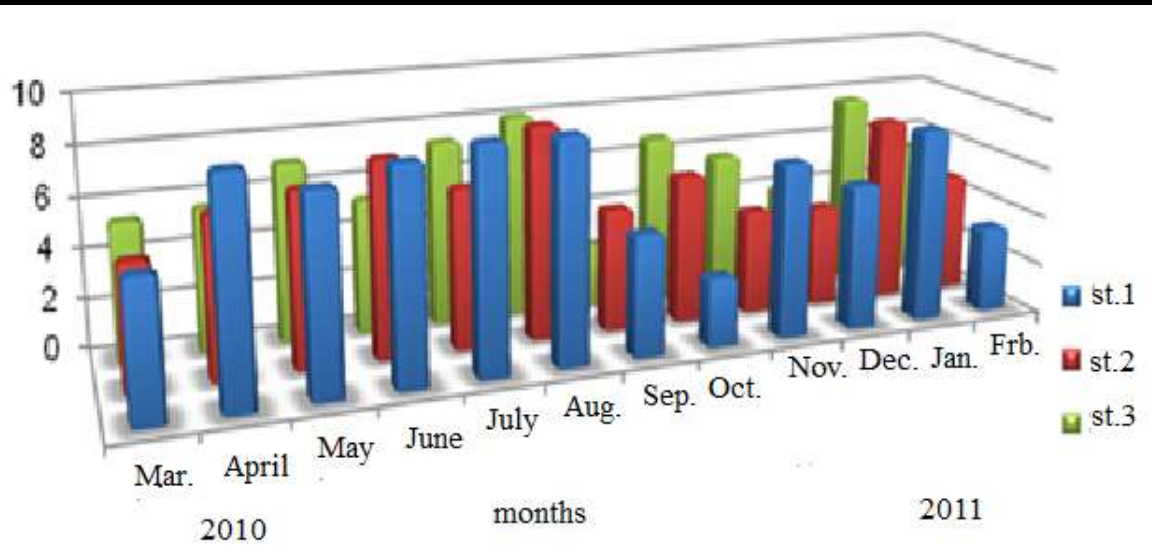

Fig.9: Species richness index for the three stations

The study stations show highlyin species richness, especially for rotifera as this group gives quantity and qualityrichness for each station, followed by copepoda, which contained abundant numerically exceeded their quantity, and less than that cladocera community, which contained few numerical and lack of quality.But in general, this indicator is based in hisaccounton the absolute number of taxonomic units, quantitative and qualitative, so it shows an envisions optimistic about the reality of the study stations in the Tigris River, which is commensurate with the availability of food productivity, as the associated change physical and chemical factors, and this means having positive relationships between the abundance of the species and the physical and chemical parameters (Al-Namrawi 2005,Nashaat 2010).

\section{Shannon Weiner Diversity Index (H) and Species Uniformity $\operatorname{Index}(E)$}

The use of diversity index is important to know the developments in the eco-system changes, where the species begin to resettle themselves when appropriate environmental conditions, and decreases when the environmental condition begins changes leading to an imbalance in the stability of the whole society. Most of the contaminated water is a little diversity, so in order to assess and appropriately pollution, is favorable to have a long observation to calculate the diversity index (Goel, 2008).

Figure (10) shows the Shanon-Weiner diversity index values, where the station 1 recorded less versatile 1.90 bits/individual in July, while the highest value in November 2.86 bits/individual. Station 2 recorded the lowest versatile (1.66 bits/individual) in May, while September recorded the highest value of diversity ( 2.99 bits/individual). In station 3 the lowest value of diversity was 1.75 bits/individual in August and the highest in February 2.87 bits/individual.

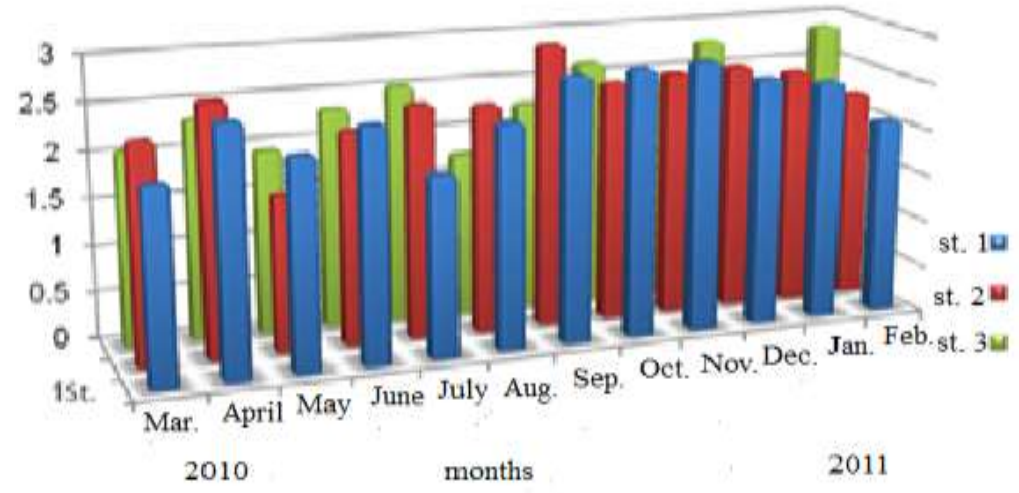

Fig.10: Shanon-Wiener diversity index values for the three stations 
Generally,this indicator varied from 1.8 bits/individual and the highest value recorded was 2.99 bits/individual.Thus, according to (Goel, 2008) this indicator was depending on the number of species and the relative abundance in the body of water, which is a sign of the quality of water in the Tigris River, which can be considered as a moderate organic pollution in 2010.

The Species uniformity index (Figure 11) recorded values ranged from 0.72 to at the station 1 in February 2011 to 0z.91 in July 2010. Station 2 scored the lowest value 0.26 in May and the highest value of 0.89 in September. While the station 3 has the lowest value of 0.66 in September 2010 and the highest value of 1.01 in February 2011 and this value is the highest among all the three stations, while the minimum value of the similarity of the species between the study stations is 0.26 during May 2010 at station 2 .

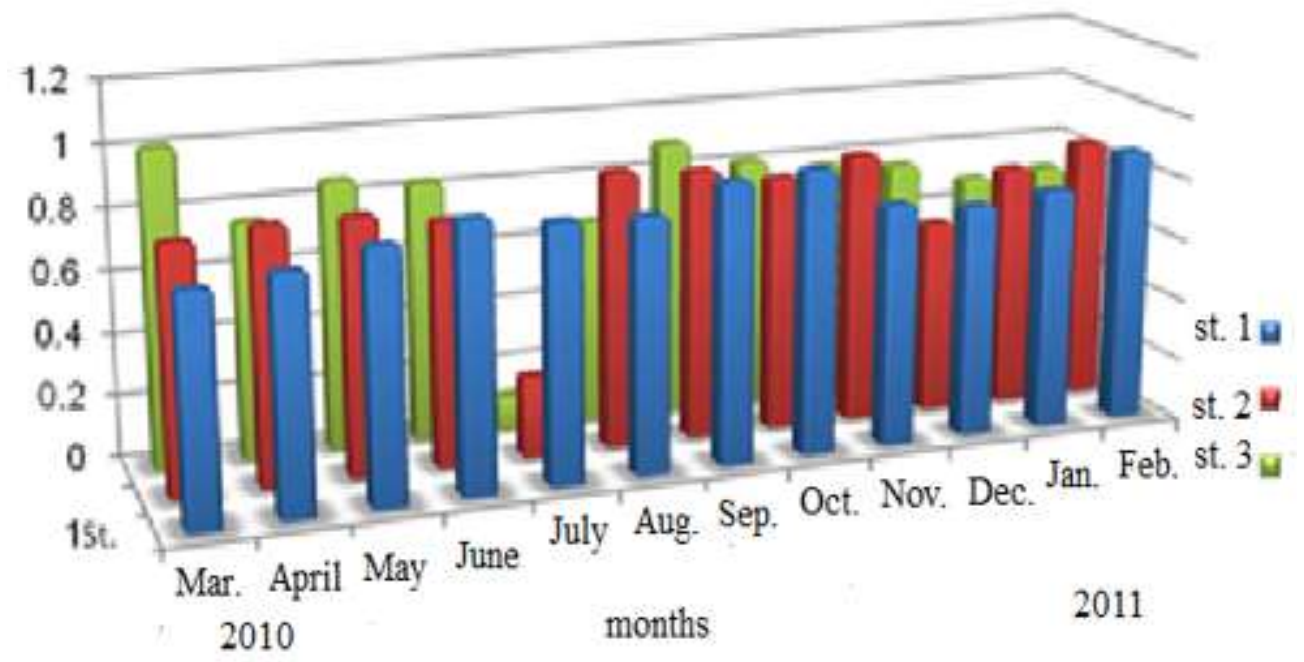

Fig.11: The species uniformity index in three stations

The highest recorded values for this indicator in these stations indicated that the environmental pressure on zooplankton species was very low, this is which referred byGreen (1993).

\section{REFERENCES}

[1] Abbas, A. K. and Al-Lami A. A. (2001).Qualitative and quantitative composition of cladocera in Tigris River, Iraq. Journal of the College of Education. 12 (4): 447-480.

[2] Ahmad, U., S. Parveen; A. A. Khan; H. A. Kabir; H. R. A. Mola and A. H. Ganai (2011). Zooplankton population in relation to physico-chemical factors of sewage fed pond to Aligarh (UP), India. Biology and Medicine. 3 (2): 333-341.

[3] Al-Aboody, Y. N. (1992). Hydro-chemical of River Tigris in Baghdad. Ms.C. Thesis, Faculty of Science, University of Baghdad. Pp. 103.

[4] Al-Lami, A. A. (2001). Zooplankton diversity in River Tigris, before and after Baghdad city. J. of Al-Fateh. 11:230-238.
[5] Al-Namrawi, A. M. (2005). Study the biodiversity of zooplankton and benthic invertebrates in the Tigris and Euphrates rivers in central Iraq. $\mathrm{PhD}$ thesis, Faculty of Science, University of Baghdad. P 161.

[6] Barbour, M. T., J. Gerritsen, B.D. Snyder and J.B. Stribling, (1999). Rapid Bioassessment protocols for use in stream and Wadeable rivers: periphyton, macroinvetebrates and fish, 2nd. Ed., EPA, U.S. Environmental Protection Agency, Office of water. Washington, DC.

[7] Claps M C, Gabellone N. A. and Benitez H. H. (2004) Zooplankton biomass in an eutrophic shallow lake (Buenos Aires, Argentiua): Spatio-temporal Variations. Ann. Limnol. Int. J. 4 (3): 201-210.

[8] Edmondson, W. T. (1959) Freshwater Biology $2^{\text {nd }}$ Ed. John Willey \& Sons, Inc., New York. 1284 pp .

[9] Elías- Gurtiérres, M.;E. Suárez- Moralesand S.S.S. Sarma (2001). Diversity neotropics: the case of Mexico. Verh. Internate. Verein. Limnol: 27, 20274031.

[10]Floder, S. and U. Sommer (1999). Diversity in plankton communities: An experimental test of the 
intermediate disturbance hypothesis. Limnol. Oceanogr. 44(4): 1114-1119.

[11] Goel, P.K. (2008) Water Pollution. Causes, Effects and Control. $2^{\text {nd }} \mathrm{Ed}$, reprint new age international $(\mathrm{P})$ Limited, Publishers, New Delhi.

[12] Green, J (1993). Diversity and dominance in planktonic rotifers. Hydrobiol. 255: 345 - 352.

[13] Iraq Water Resources (2011).Discharges and the levels of the Tigris River in the city of Baghdad.The National Centre for Resource Management Department Control of Water

[14] Nashaat, M. R. (2010). Impact of Al-Durah Power plant effluents on physical, Chemical and invertebrates Biodiversity in Tigris River, Southern Baghdad, PH.D. Thesis, University of Baghdad, Iraq. 183 pp.

[15] Omori, M. and T. Ikeda (1984). Methods in marine zooplankton ecology. John Wiley and Sons, Inc. New York.

[16] Petersen F. D., Papa S. R. and Mamaril A. C. (2010) To the Philippine Freshwater Zooplankton. University of Santo Tomas, Manila, Philippines, $330 \mathrm{pp}$.

[17] Porto-Neto, V.F.(2003). Zooplankton as bioindicator of environmental quality in the Tamandane Reff System (Pernambnco- Brazil): Anthropogenic influences and interacts with mangroves. $\mathrm{Ph}$. D. Thesis, Univ. Bremenm Brazil.

[18] Rajashekar, M , Vijaykumar K , Parveen Z (2009) Zooplankton diversity of three freshwater lakes in relation to trophic stats, Gulparga district, North- East Karnataka, South India. Inter. J. of systems Biology, 1(2): 32-37.

[19] Shekha, Y. A. (2008). The effect of Erbil city wastewater discharge on water quality of Greater Zab River, and the risks of irrigation. Ph.D. Thesis, College of Science- University of Baghdad. $139 \mathrm{pp}$.

[20] Sklar, F. H. (1985). Seasonality and community structure of the Back Swamp invertebrates in Alonisiana Tupelo Wetlands. Wetlands. J. 5: 69-86.

[21] Smith, P. J. (1999). Managing Biodiversity: Invertebrate by catch in sea mount Fisheries in the New Zealand exclusive economic Zone. National Institute of Water and Atmospheric Resaech. New Zealand.

[22] Smith, D. G. (2001) Pennak's Freshwater invertebrates of the united States. $4^{\text {th }}$. Ed., John Willey \& Sons, Inc. New York. 538 pp.

[23] Solomon, S. G. Ataguba, G. A. \& Baiyewunmi, A. S. (2009). Study of dry season Zooplankton of lower
River Benue at Makurdi, Nigeria. J. of Animal \& Plant Sciences, 1(3): 42-50. 